by Fritz F. Steininger, M. P. Aubry, W. A. Berggren, M. Biolzi, A. M. Borsetti, Julie E. Cartlidge, F. Cati, R. Corfield, R. Gelati, S. Iaccarino, C. Napoleone, F. Ottner, F. Rögl, R. Roetzel, S. Spezzaferri, F. Tateo, G. Villa, D. Zevenboom

\title{
The Global Stratotype Section and Point (GSSP) for the base of the Neogene
}

\begin{abstract}
The Paleogene-Neogene Period-System boundary, which defines also the Oligocene-Miocene Epoch -Series boundary is defined in the Lemme-Carrosio section in the village of Carrosio, south of the town of Gavi and north of Voltaggio (Alessandria Province), northern Italy.
\end{abstract}

\section{Historical background and concepts}

The historical background of the concepts of 'stratigraphic units' of Lyell (1833) and of M. Hörnes (1853) (the Chronostratigraphic Units of modern usage) have been based mainly on two observations: (1) major or minor discontinuities (or facies changes) in rock sequences and (2) major or minor changes in the overall biotic content, or within a specific taxonomic group. M. Hörnes (1853) defined the Neogene using both characteristics. In his work published in 1853 (p. 806) Hörnes discussed his 'organic' (paleontologic) reasons for combining Lyell's (1833) Miocene and Pliocene into his Neogene by referring to the mollusc fauna: 'die Verschiedenheit der ('of the mollusc') Fauna der Eocän- und Miocän-Epoche' of Lyell and in 1864 (p. 510) he pointed out the widespread discontinuities: 'Unstreitig haben zwischen der Eocen- und Neogenzeit gewaltige Schichtstörungen in Europa stattgefunden'.

\section{Concepts of the Working Group}

The base of the Neogene System and the base of the Miocene Series must be situated between the Chattian and Aquitanian Stages, so that the Aquitanian Stage is included in the Neogene System. The Paleogene-Neogene System Boundary coincides with the Oligocene-Miocene Series Boundary. The ideal GSSP candidate for the Paleogene-Neogene System boundary would be a temporally continuous section representing the so called 'critical time span'. This 'critical time span' was determined to be represented by the biostratigraphic interval between planktonic foraminiferal Zones P21 to M2 of Berggren et al. (1995). In terms of calcareous nannofossil zonation it corresponds to the interval from Zone NP25 (Spenolithus ciperoensis Zone) to Zone NN2 (Discoaster druggi Zone) as defined by Martini (1971) and Martini and Müller (1986).

\section{Main features of the proposed GSSP}

Name: Base of the Neogene System (base of the Miocene Series, Paleogene-Neogene System boundary and Oligocene- Miocene Series boundary).

Rank of the boundary: System (beginning of the Neogene Period) Locality name of the GSSP: Lemme-Carrosio section, Italy. Geographic position: Longitude $8^{\circ} 50^{\prime} 11^{\prime \prime} \mathrm{E}$; Latitude: $44^{\circ} 39^{\prime} 32^{\prime \prime}$ N. Carta Geologica d'Italia: Foglio GENOVA No. 82 (1:100 000); Tav. VOLTAGGIO I NE (1: 25 000) (Figure 1).
Local position: $35 \mathrm{~m}$ from the top of the Lemme-Carrosio Section. Sedimentological marker: An excellent lithological marker for the GSSP is provided by a distinct boundary between lithologic Unit A (the more massive part of the section) and the overlying lithologic Unit B-1 (the more stratified part of the section) At the $50 \mathrm{~m}$ mark, there is a horizon with yellowish nodules. The GSSP is exactly 15 metres above this lithologic boundary. A layer with yellowish nodules lies in lithologic Subunit B 2, exactly one metre below metre 35 (Figure 3).

Artificial marks: The top of the section $(0 \mathrm{~m})$ corresponds to the top of the Rigoroso Formation. For practical reasons, a metal stake was not placed at level 0 but exactly $0.50 \mathrm{~m}$ below the top of the formation. A steel cable runs from the $0 \mathrm{~m}$ mark to the base of the section. Each metre of the section is marked by a metal tag (with the metre number). These tags are fixed at the cable and additionally in the for-

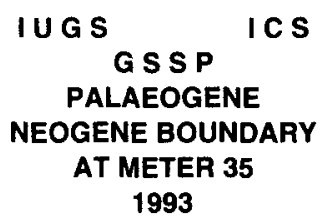

mation. In addition metre 35 is marked by a metal plaque fixed in the section with the following text.

The section has excellent exposure, absence of major structural complications and apparent absence of unconformities within the so called 'critical time span'. In addition, there is an adequate thickness of sediments, favorable facies, rather good potential for planktonic

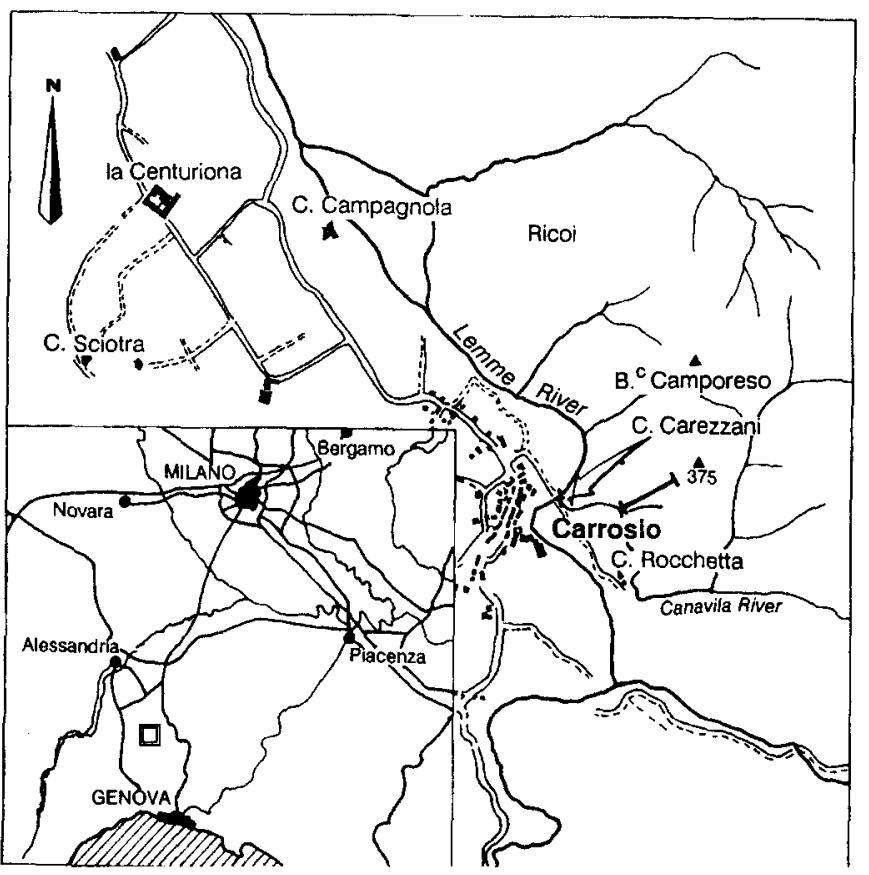

Figure 1 Geographic location of the Lemme-Carrosio section. 
and benthic microfossil biostratigraphies, magnetostratigraphy, stable isotope stratigraphy and, eventually cyclostratigraphy.

The section is easily accessible by public and private transportation and the present owner of the property Mr. Nando Traverso has agreed to provide access to colleagues interested in visiting and sampling the section and to conserve the section as an international geological point of prime interest.

\section{Geology of the GSSP site}

The area of the Lemme-Carrosio section is situated within the Piedmont Tertiary Basin, in southern Piedmont, northwestern Italy (Figure 2). The basin itself is bordered by the arc of the Western Alps and by the northwestern end of the Northern Apennines. Its basement is formed by Pennidic and Ligurian tectonic units. The late Eocene to late Miocene succession forms a large homocline, gently dipping to the northwest. The basin formed during the late Eocene-early Oligocene as an extensional basin behind the arc of the Western Alps. It was affected by the Apennine compression from late Oligocene. Evidence of post late Miocene extensional tectonics are clearly recorded (Falletti et al., 1994). The facies evolution of the Piedmont Tertiary Basin is strongly controlled by synsedimentary tectonic activity and three large-scale facies belts can be recognized. From west to east: the Langhe-, the Visone-Lemme- and the Borbera-Staffora facies belts. The GSSP section is situated within the Visone-Lemme facies belt in the upper part of the Rigoroso Formation which overlies the Molare Formation (Oligocene fan delta conglomerates with sandy shallow marine intercalations yielding micro-

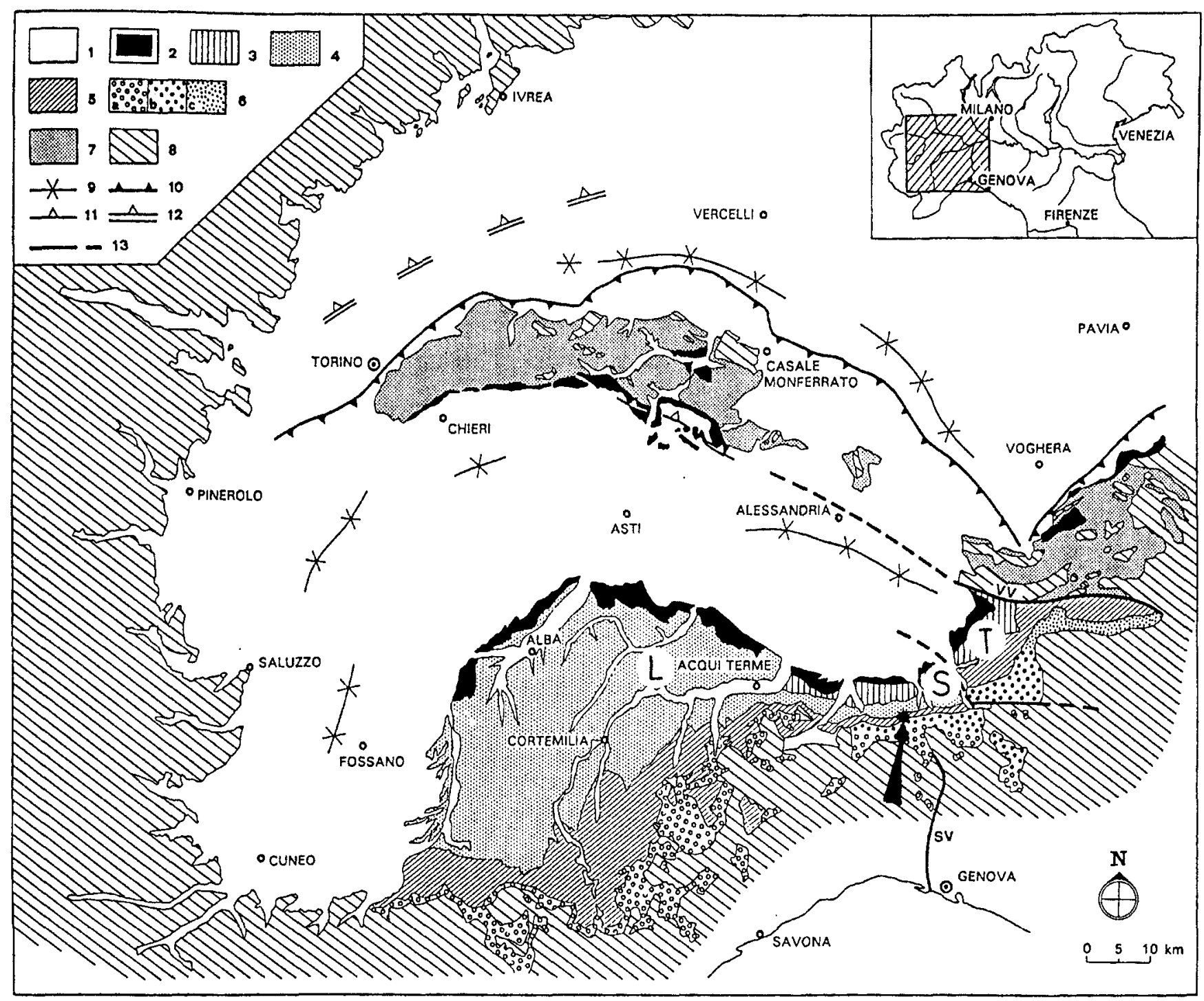

\section{Figure 2 The geologic frame of the Piedmont Tertiary Basin.}

$\mathrm{L}$ Location of the Langhian type section.

S Location of the Serravallian type section.

$T$ Location of the Tortonian type section.

1 Pliocene to Recent deposits.

2 Messinian deposits.

3 Langhian to Tortonian siliciclastics and carbonates shelf and slope deposits.

4 Upper Burdigalian to Tortonian mainly turbiditic succession (only Burdigalian in the Eastern sector of this figure).

5 Upper Oligocene to Burdigalian turbidites and hemipelagic mudstones.
6 Upper Eocene to lower Oligocene deposits: a alluvial to coastal conglomerates, shallowwater sandstones and hemipelagic mud stones;

b slope and base-of-slope, resedimented con glomerates; c mainly turbidites.

7 Late Eocene to Tortonian mainly siliciclastic deposits of the NW Apennines-Basso Monferrato-Collina di Torino wedge.

8 Alpine and Apenninic allochthonous units.
9 Depo-center axis of the Plio-Quaternary basins.

10 Buried thrust front of the Collina di Torino Basso Monferrato-NW Apennine wedge.

11 Buried, south vergent backthrust of the Basso Monferrato, active from Messinian onward.

12 Buried, pre-Burdigalian backthrust of the western Alps (as inferred from Roure et al., 1990).

13 Tectonic lines: SV Sestri-Voltaggio, VV Villalvernia-Varzi. 


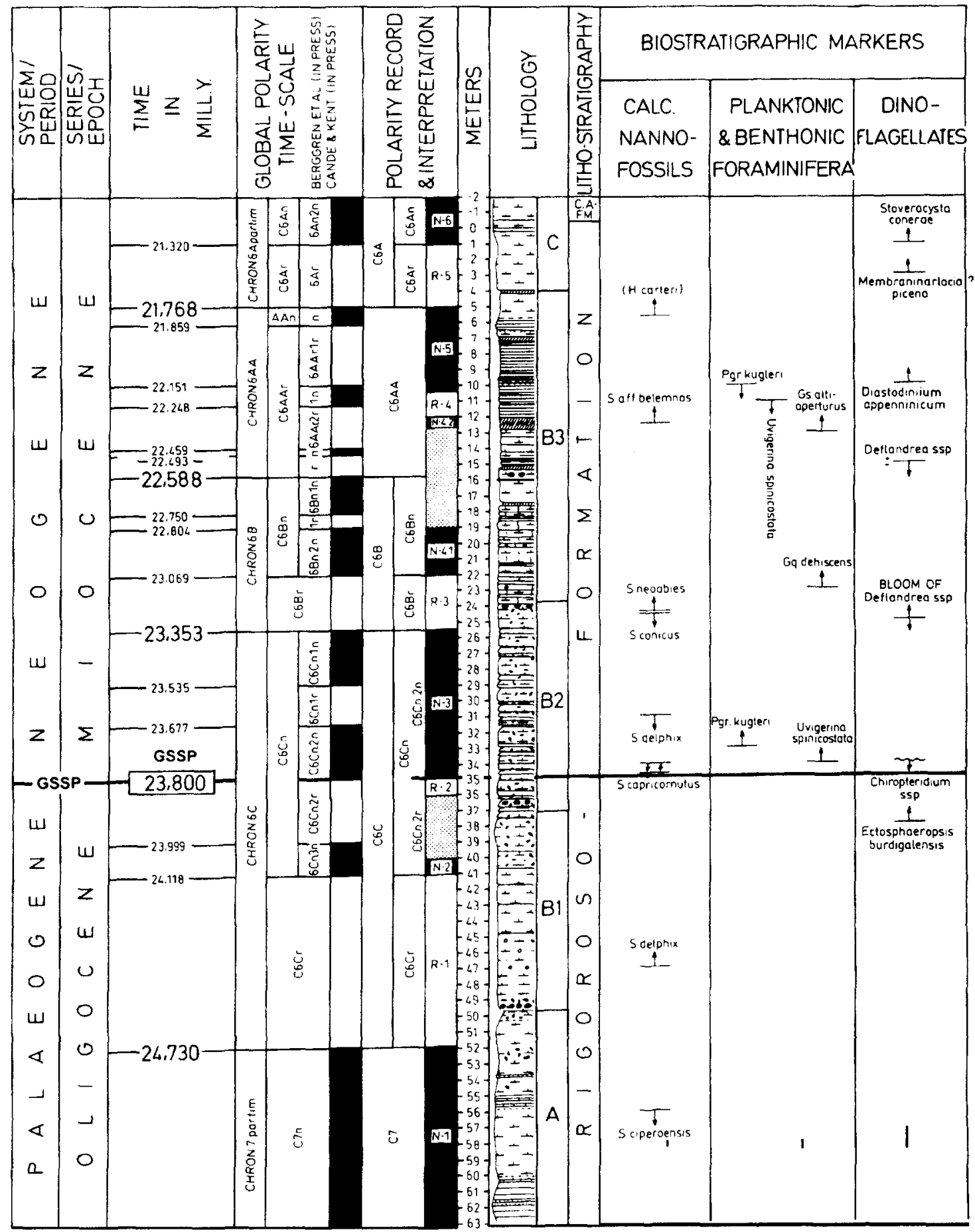

Figure 3

Chronostratigraphy, Geochronology, Magnetostratigraphy, Lithostratigraphy and Biostratigraphy of the Lemme-Carrosio Section.

and macrofauna). The Molare-Formation lies unconformably on a pre-Cenozoic substratum (Gnaccolini, 1978a, b). The Rigoroso Formation itself is overlain by the upper lower Miocene Costa Montada Formation.

\section{Lithology}

In the Lemme section (Figure 3), the Rigoroso Formation is characterized by poorly to very poorly sorted sediments which can be classified as fine and medium grained silts with fine silts dominating. The $\mathrm{CaCO}_{3}$ content shows a prominent decrease at metre 35.00. The measured section can be divided into three lithologic units as follows.

Unit A (from metre 63 to metre 49.5: 13.50 metres exposed). The basal Unit $A$ is characterized by bluish-grey, massive, partly indis- tinct fine bedded, clayey to fine sandy silts. Yellow to orange marks and nodules may represent bioturbation structures.

Unit B (from metre 49.5 to metre 4 : total thickness 45.50 metres). This interval that is noticeably more fine-grained forms the main part of the section. It can be subdivided into three subunits.

Lower subunit B 1 (from metre 49.5 to metre $37: 12.50$ metres): massive to indistinctly bedded, blush-grey, clayey silts with few, thin laminated, more clayey pelitic layers. Yellow to orange marks and nodules as in Unit A.

Middle subunit B 2 (from metre 37 to metre 24: 13 metres). This characteristic subunit consists of massive, indistinctly bedded, silty intervals alternating with thinly bedded, wavy laminated, more-clayey pelitic layers. Yellowish to orange colored nodules occur in the massive blueish-grey silts and form marker hori- 
zons. This unit which is characterized by fining upwards cycles consists probably of turbidites. The GSSP of the base of the Neogene System was defined 2 metres above the base of Subunit B 2, just one metre above a very distinct layer with yellowish to orange colored nodules.

Upper subunit B 3 (from metre 24 to metre 4: 20 metres): massive, indistinctly bedded blushgrey silts with wavy laminated more clayey pelitic intercalations and several metres of thin laminated, mostly clayey pelites.

Unit C (from metre 4 to metre minus 2: 6 metres): in general massive blush-grey silts with only a few laminated and more clayey pelitic intercalations. The silts change towards the top of Unit $\mathrm{C}$ into fine sandy silts. The Costa Montada Formation overlies unconformably Unit C.

\section{Mineralogy}

The dominant minerals are phyllosilicates and calcite, with various amounts of feldspar, quartz, dolomite, serpentine and pyrite. The main part of the clay-fraction consists of high charged smectite, with minor amounts of illite, kaolinite, chlorite and even serpentine.

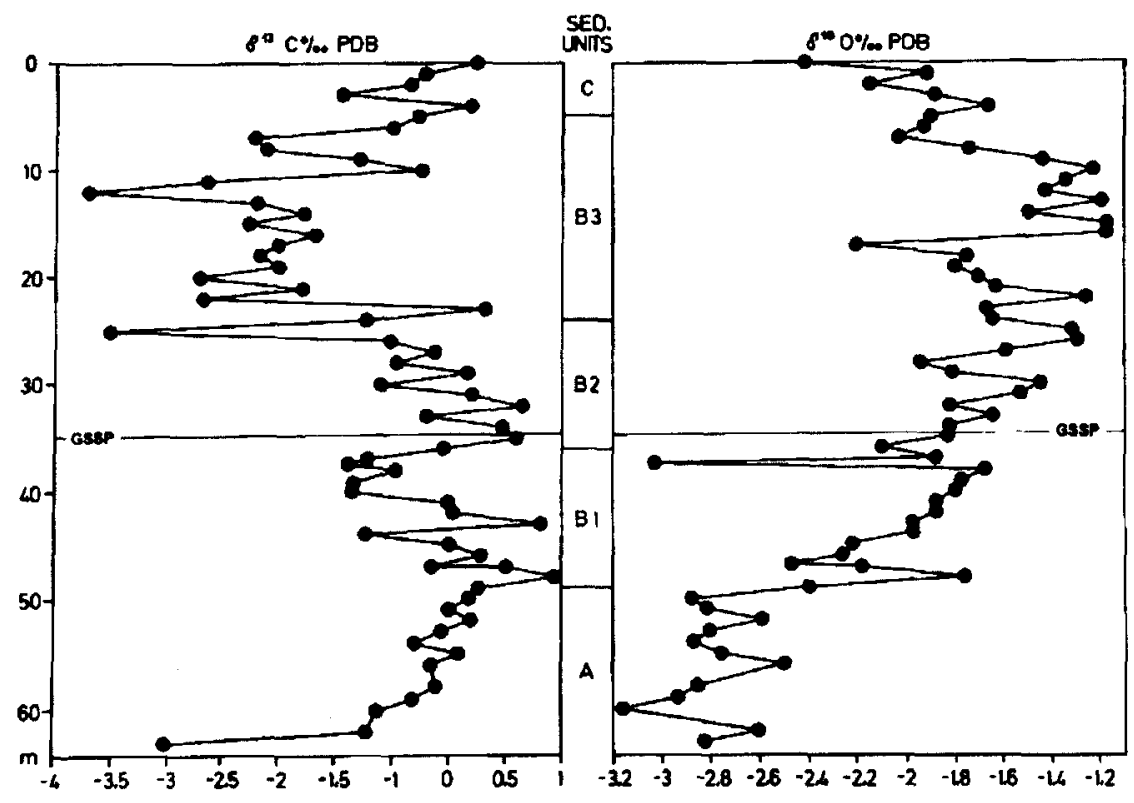

Figure 4 Carbon isotope and oxygen isotope stratigraphy of the Lemme-Carrosio Section.

\section{Biostratigraphy}

The GSSP is bracketed by a set of biostratigraphic events in planktonic microfossil groups (calcareous nannofossils, planktonic foraminifera and dinoflagellate cysts). The preservation of calacareous micro- and nannofossils is moderate to poor, while the dinocyst preservation is good to excellent. The planktonic microfossil groups exhibit moderate diversity and the frequency of the index fossils varies with the quality of preservation (poor to moderate to good to excellent). In the calcareous nannofossil assemblages, reworking prevents use of highest occurrence datums which elsewhere have proven to be useful, such as the HO of Zygrhablithus bijugatus and of Reticulofenstra bisecta. The abbreviations LO and HO indicate lowest and highest occurrence levels for each species (Figure 3).

\section{Calcareous nannofossils}

LO of Spenolithus ciperoensis 21 metres below metre 35.00; LO of Sphenolithus delphix 12 metres below metre 35.00; LO and HO of Sphenolithus capricornutus within one metre above metre 35.00 and $\mathrm{HO}$ of Sphenolithus delphix, 4 metres above metre 35.00 .

\section{Planktonic foraminifera}

LO of Paragloborotalia kugleri two metres above metre 35.00, HO of Paragloborotalia kugleri 25 metres above metre 35.00; LO of Globoquadrina dehiscens 12 metres above metre 35.00, LO of Globigerinoides altiaperturus 22 metres above metre 35.00 .

\section{Benthic foraminifera}

The LO of Uvigerina spinicostata one metre above metre 35.00 .

\section{Dinoflagellate cysts}

LO of Ectosphaeropsis burdigalensis at metre 38.00; highest abunance of Chiropteridium spp. at metre 39.00 and approximate HO of Chiropteridium spp. one metre above metre 35.00 ; bloom of Deflandrea spp. about 10 metres above metre 35.00 and highest abundance Deflandrea at metre 15.00; LO of Distatodinium apenninicum at metre 10; LO of Membraninarlacia ?picena at metre 3.00 and LO of Stoveracysta conerae at metre 1.00.

From the base of the section to metre 34.00 the planktonic foraminiferal assemblage is of low diversity. From metre 33.00 to metre 23.00 a remarkable change in diversity occurs with an acme of the genus Globigerinoides comparable to the deep sea record outside the Mediterranean (Keller, 1981; Spezzaferri, 1991, 1994). From metre 21 to the top of the section the foraminiferal assemblages are well diversified. In addition from metre 11 up to the top of the section, radiolaria (well known to occur in this stratigraphic position of the Mediterranean area) occur in great abundance (Sanfilippo et al., 1973).

\section{Depositional environment and paleoclimatological- paleotemperature interpretations}

The lithology and the benthic foraminifera assemblages indicate a middle bathyal environment ( 600 to $1000 \mathrm{~m}$ water depth). The planktonic foraminiferal assemblages suggests that warm conditions and strong upwelling prevailed during deposition of the lower part (up to metre 40) of the section. In general cooler conditions and paleoclimatic instability with low magnitude cool water fluctuations are registered in the interval between metre 40 and metre 10 . The uppermost part of the section yields evidence of deposition under warm water conditions. This paleoclimatic trend is consistent with that observed in the open ocean. This paleoclimatic instability may be responsible for the discrepancies in the stratigraphic ranges between the Lemme section and other sections. The oceanic dinoflagellate species Impagidinium div.sp. and Nematospaeropsis div.sp. are used to approximate the sea surface temperature conditions. They indicate a cooling trend during deposition of the lower part of the section up to metres 40-39; a 'sudden' warming pulse up to metre 36-35; a relative cool pulse up to metre 24-23; a warming pulse up to metre 15-14 and a relative cool pulse upwards, briefly interrupted at metre $4-3$ to metre $2-1$ of the section.

\section{Magnetostratigraphy}

Biostratigraphic correlations allow the interpretation of the geomagnetic pattern of this section using the magnetobiochronologic scale of Berggren et al. (1995) (Figure 3). Association of the distinct polarity reversals at metre 35 with the biostratigraphic events cited above permit identification of the magnetozones delineated between as Chron $\mathrm{C} 6 \mathrm{Cn} .2 \mathrm{r}$ and $\mathrm{Chron} \mathrm{C} 6 \mathrm{Cn} .2 \mathrm{n}$ respectively. This unambiguous reversal pattern and the associated excellent biostratigraphic 
markers have been among the main reasons for defining the base of the Neogene at metre 35 of the Lemme-Carrosio section. Magnetostratigraphy and stable isotope stratigraphy have provided good and internally consistent results, which can be interpreted in a relatively unequivocal manner.

\section{Stable Isotope Stratigraphy}

Stable isotope studies were performed on whole rock carbonates (Figure 4). Oxygen: The oxygen isotope record shows a systematic enrichment in $\delta^{18} \mathrm{O}$ from the base of the section up to approximately metre 15. This may correlate in whole or in part with the cooling trend identified by foraminiferal abundance analyses or may reflect the ice-volume growth event labelled Mi-1 by Miller et al. (1991), Oslik et al. (1994) and van Eijden and Ganssen (1995). Carbon: Carbon isotope signals of $-1.5 \%$ are recognized between 40 and 35 metres. These signals can be compared in position to the carbon signals shown by Miller et al. (1991), Oslik et al. (1994) and van Eijden and Ganssen (1995).

\section{Sequence stratigraphy and sea-level changes}

Integrated magnetostratigraphy and planktonic foraminiferal stratigraphy allow correlation with the eustatic sea-level chart of Haq et al. (1988). As indicated by the planktonic foraminifera (LO of Paragloborotalia kugleri) the section appears to coincide with TB 1.4 (estimated age $24.8 \mathrm{Ma}$ ) of $\mathrm{Haq}$ et al. (1988). The section would fall within the Supercycle TB 1, the GSSP (metre 35) within the lower part of the highstand of TB 1.4. According to the distribution of the dinoflagellate cysts whose abundance record sealevel fluctuations, it is likely that the lower part of the section up to metre 39-38 was deposited during a sea level fall (upper part of Dbi Zone resp. ChiSubzone) $=$ TB 1.3, changing to a sea-level rise up to metre 10-9 (lower part of Ebu Zone resp. entire Def Subzone) $=$ TB 1.4, followed by a sea-level fall (upper part of Ebu Zone, resp. entire DapSubzone $)=\mathrm{TB} 1.4$ to $\mathrm{TB} 1.5$.

\section{Global correlation}

The GSSP is potentially correlatable worldwide by means of magnetostratigraphy, marine microfossil biostratigraphy, and/or stable isotop stratigraphy. In addition magnetostratigraphy allows recognition of this level in the continental stratigraphic record. Magnetostratigraphy also provides the means for indirect correlation between marine and marine biostratigraphic zonations.

\section{Marine Biostratigraphic correlation}

Calcareous nannofossils approximately base of Zone NN1 (Tri quetrorhabdulus carinatus Zone); approximately base of Subzone CNIA.

Planktonic foraminifera base of Paragloborotalia (so called Globorotalia) kugleri TRZ Zone equivalent to the base M 1 Zone; base of Mt 1 and base of (Sub) Antarctic Zone AN 1 (Berggren and al., 1995).

Radiolaria base of Lychnocanoma elongata Zone; uppermost part of Zone 14 (= Dorcadospyris ateuchus Zone).

Diatoms

North Pacific: $\quad$ lowermost portion of Thalassiosira spinosa PR Zone.

Southern Ocean-Antarctic: upper part of the Rocella gelida Zone. Low latitudes: within the Rocella gelida PR Zone

The consensus for all three areas is that the GSSP for the base of the Neogene falls within the Rocella gelida PR Zone (obviously near the top of the Zone).
Silicoflagellates

within the Distephanus speculum haliomma Subzone of the Naviculopsis biapiculata Zone.

Dinoflagellate cysts base of Cordosphaeridium canthaerelum Zone; DO-3B Subzone at the uppermost part of DO-3 Zone; Def Subzone within lowermost Ebu Zone.

\section{Continental biostratigraphic correlation}

European Mammals MP 30 resp. near the base of MN 1 Zone (characteristic mammalian taxa are rodents of the family Eomyidae: Rhodanomys transiens); within the Agenian mammal faunal Unit, in the "unnamed" continental Stage below the Ramblian Stage of the European Continental Stage concept.

North American Mammals between late early Arikareean and the base of late Arikareean.

Pollen East Mediterranean: above Kale Pollen Zone. Central Paratethys: approximately between Zones NG I and NG II.

Charophytes base of Rantzieniella nitida Zone; respectively top of Stephanochara berdotensis Zone.

\section{Regional chronostratigraphic equivalents}

Mediterranean

at or just below the base of the stratotype of the Aquitanian Stage.

Northern Europe

Central Paratethys

Eastern Paratethys

probably within the uppermost part of the (Neo-) Chattian Stage. within the upper Egerian Stage. within the upper 'Caucasian' Stage (i.e., near the boundary between the Kalmykian and the Karadzhalgian Stages (Popov et al., 1993).

North America East coast, Gulf coast uppermost Hackberryian Stage;

N American West coast uppermost Zemorrian Stage.

New Zealand upper Duntroonian Stage

East Indian Letter Stages uppermost e4-lowermost e5-Letter Stage.

\section{References}

Andreoni, G, Galbiati, B, Maccabruni, A, and Vercesi, P L., 1981, Paleogeografia dei depositi Oligocenici superiore - Miocenici inferiore nell estremità orientale del Bacino Ligure Piemontese: Rivista Italiana Paleontologia et Stratigraphia, v. 87, pp. $245-282$

Berggren, W A., Kent, D V, Swisher ,III C, and Aubry, M P, 1995, A Revised Cenozoic Geochronology and Chronostratigraphy, in: Berggren, W A., Kent; D V, Aubry, M P and Hardenbol, J (editors). Geochronology, Time Scales and Global Stratigraphic Correlations: SEPM Special Vol. 54, pp. 130-212

Brinkhuis, H, Powell, A J, and Zevenboom, D, 1992, High-resolution dinoflagellate cyst stratigraphy of the Oligocene-Miocene transition interval in north-west and central Italy: in: Head, M J, and Wrenn, J $\mathrm{H}$,(editors.), Neogene and Quaternary dinoflagellate cysts and acritarchs: American Association Stratigraphic Palynology Foundation, pp. 219-258

Bronn, H G, 1838, Lethea Geognostica, oder Abbildungen und Beschreibungen der für die Gebirgsformationen bezeichnensten Versteinerungen, v. 2, pp. $545-1356$

van Eijden, A J M, and Ganssen, G M, 1995, An Oligocene multi-species foraminiferal oxygene and carbon isotope record from ODP Hole 758A (Indian Ocean): paleoceanographic and paleo-ecologic implications, Marine Micropaleontology, v. 25, pp. 47-65

Falletti, P, Gelati, R, and Rogledi, S, 1994, Oligo-Miocene Evolution of episutural and perisutural basins at the Alps-Apennines boundary, RCMNS-Colloquium Rabat 
Galbiati, B, 1976, La successione Oligo-Miocenica tra Rigoroso e Carrosio (Bacino Ligure-Piemontese), Atti Istituto Geologia Universita Pavia, v. 26, pp. $30-40$

Gnaccolini, M, 1978a, L'Unità di S. Rocco' nella Formazione di Molare tra le valli del T. Stura e del T. Lemme, Rivista Italiana Paleontologia Stratigraphia, v. 84, pp. $411-442$

Gnaccolini, M, 1978b, Depositi oligocenici di 'fan delta' nella regione compresa tra Bosio e la Costa Cravara (Bacino Terziario Ligure-Piemontese).- Rivista Italiana Paleontologia Stratigraphia, v. 84, pp. 673 - 699

Haq, B U, Hardenbol, J, and VAIL, P R,1988, Mesozoic and Cenozoic chronostratigraphy and cycles of sea-level change, SEPM Special Publication, no. 42, pp. 71-108

Hörnes, M, 1853, Mittheilung an Prof. Bronn gerichtet. Wien, 3. Okt., 1853 , - Neues Jahrbuch Mineralogie Geologie Geognosie und Petrefaktenkunde,.pp. $806-810$

Hörnes, M, 1864, V. Die fossilen Mollusken des Tertiärbeckens von Wien,Jahrbuch Geologische Reichsanstalt, v. 14, pp. 509 - 514

Keller, G, 1981, Miocene biochronology and paleoceanography of the Northern Pacific, Marine Micropalentology, v. 6, pp. 535 - 551

Lyell, Ch, 1833, Principles of Geology, v. 3, 398 p., London, Murray

Martini, E, 1971, Standard Tertiary and Quaternary calcareous nannoplankton zonation, Proceedings 2nd Planktonic Conference, pp. 739 - 785 , Rome, Tecnosci

Martini, E, and Müller, C, 1986, Current Tertiary and Quarternary calcareous nannoplankton stratigraphy and correlations, Newsletter Stratigraphy, v. 16, pp. $99-112$

Miller, K G, Feigenson, M D. Wright, J D, and Clement. B M. 1991. Miocene isotope reference section, Deep Sea Drilling Project Site 608: an evaluation of isotope and biostratigraphic resolution, Paleoceanography v. 6, pp. $33-52$

Naumann, C F, 1858, Lehrbuch der Geognosie, 2nd.edition, v. 3, pp. 1-576, Leipzig, Engelmann

Oslik, J S, Miller, K G, Feigenson, M D, and Wright, J D, 1994, OligoceneMiocene strontium isotopes: Stratigraphic revisions and correlations to an inferred glacioeustatic record.- Paleoceanography, v. 9, pp. 427 - 443

Popov, S V, Akhmetiev, M A, Zaporozhets, N I, Voronina, A A, and Stolyarov, A S, 1993, Evolution of Eastern Paratethys in the late EoceneEarly Miocene.- Stratigraphy and Geological Correlation, v. I(6), pp. 10 $-39$

Sanfillipo, A., and Negrini, C, (in press), Radiolarian Stratigraphy across the Oligocene - Miocene Transition.- Marine Micropaleontology
Spezzaferri, S, 1991, Evolution and taxonomy of the Paragloborotalia kugleri (Bolli) lineage, Journal Foraminiferal Research, v. 21, pp. 313-318

Spezzaferri, S, 1994, Planktonic foraminiferal biostratigraphy and taxonomy of the Oligocene and lower Miocene in the oceanic record. An overview, Palaeontographica Italica, Raccolta Monographia Paleontologia, v. 81. $187 \mathrm{p}$

Steininger, F F, Bermpr, R L, and Fahlbusch, V, 1989, European Neogene marine-continental chronologic correlations, in: Lindsay, E $\mathrm{H}$. Fahlbusch, V, and MEIN, P, (editors), European Neogene mammal chronology, Proceedings NATO Advanced Research Workshop, v. 180 , pp. 15-46, New York, Plenum Press

Steininger; F F, Berggren, W B, Kent, D V, Bernor; R L, Sen, S, and Agusti. J, 1996, Circum Mediterranean Neogene (Miocene and Pliocene) Marine - Continental Chronologic Correlations of the European Mammal Units and Zones, in: Bernor, R L. Fahlbusch, V, and Rietschel, S, (editors). Later Neogene European Biotic Evolution and Stratigraphic Correlation

Vervloet, C C. 1966, Stratigraphical and micropaleontological data on the Tertiary of southern Piemont, 88 pp., Utrecht, Schotanus et Jens

Professor Fritz F. Steininger is now Director of the Senckenberg Research Institution and Natural History Museum in Frankfurt/Main. Germany. He was previously Head of the Paleontology Department at the University of Vienna, Austria where he taught Paleontology and Stratigraphy. His researches have concentrated on the Paleogene and the Neogene and he has been involved in several IGCP Projects. A former chairman of the ISC Subcommission on Neogene Stratigraphy, he is currently Chairman of the German Stratigraphic commission.

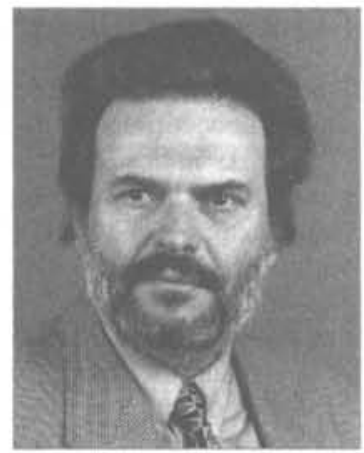

\title{
CALL FOR PAPERS
}

Episodes is the quarterly science and news journal of the International Union of Geological Sciences (IUGS). It focuses on the publication of results of scientific research and other information addressing issues of interest to the global earth-science community. Special emphasis is given to topics involving geological aspects of population growth and economic development and their resulting impacts on or implications for society. As the principal publication of the IUGS, Episodes also carries information about IUGS scientific programs and activities to the extent necessary to communicate effectively with the worldwide IUGS constituency.

Contributions of the following types of manuscripts are here solicited:

- scientific articles

- conference reports

- news and views

- letters to editor

- book reviews

- information on training courses (especially those geared to participants from developing countries)

- noteworthy new publications, including national or regional geologic maps

Please address all contributions to:

\author{
The Editor \\ Episodes \\ P. O. Box 823, 26 Baiwanzhuang Road \\ 100037 Beijing, CHINA \\ Tel: +86-10-68320827; Fax: +86-10-68328928; E-mail: Episodes@public.east.cn.net
}

